\title{
ASSESSMENT OF FERTILITY STATUS OF SOILS USED FOR CASSAVA PRODUCTION IN OWERRI, AREA OF IMO STATE, NIGERIA
}

\author{
Chinyere Chikere-Njoku \\ Department Of Soil Science and Environment, \\ Imo State University, P.M.B 2000 Owerri, Nigeria \\ e-mail: chikerenjoku@gmail.com
}

\begin{abstract}
The fertility status of soils used for cassava production in Owerri area of Imo State Nigeria was assessed. Composite samples were collected from ten different sites at $0-15 \mathrm{~cm}$ and $15-30 \mathrm{~cm}$ depth. Soil samples were prepared and analyzed in the laboratory using standard methods. Data generated were statistically analyzed using the co-efficient of variation and standard deviation. Results showed that the soils varied from sandy loam to sandy clay loam and strongly acidic (mean pH. 5.68). Apart from base saturation which is high. $77.93 \mathrm{~g} / \mathrm{kg}(0-15 \mathrm{~cm}) 79.18 \mathrm{~g} / \mathrm{kg}(15-$ $30 \mathrm{~cm})$ other parameters were low in organic matter $(O M) 1.05 \%(0-15 \mathrm{~cm}), 1.21 \%(15.30 \mathrm{~cm})$, total nitrogen $(N) 0.09 \%(0.15 \mathrm{~cm}), 0.11 \%(15-30 \mathrm{~cm})$, exchangeable potassium $(\mathrm{k}), 0.19$ $\mathrm{cmoI} / \mathrm{kg}(0-15 \mathrm{~cm}), 0-23 \mathrm{cmol} / \mathrm{kg}(15-30 \mathrm{~cm})$, available phosphorus $(p) 12.95 \mathrm{mg} / \mathrm{kg}(0-15 \mathrm{~cm})$, $17.46 \mathrm{mg} / \mathrm{kg}(15-30 \mathrm{~cm})$ Calcium (ca) $2.49 \mathrm{cmol} / \mathrm{kg}(0-15 \mathrm{~cm}), 3.31 \mathrm{cmol} . \mathrm{kg}(15-30 \mathrm{~cm})$, Magnesium (mg) $1.39 \mathrm{cmol} / \mathrm{kg}(0-15 \mathrm{~cm}), 2.10 \mathrm{cmol} / \mathrm{kg})$, Sodium $(\mathrm{Na}) 0.13 \mathrm{cmol} / \mathrm{kg}(0-15 \mathrm{~cm})$, $0.16 \mathrm{cmol} / \mathrm{kg}(15-30 \mathrm{~cm})$. The result indicates that the fertility status of the study area is low and requires intensive fertility restoration programme for soil health improvement. To boast high crop yields, and productivity of cassava in the study area, a combination of organic and inorganic fertilizers are recommended.
\end{abstract}

Keywords: soils, fertility status, soil productivity, cassava yields, Owerri.

https://dx.doi.org/10.4314/jafs.v15i2.1

\section{INTRODUCTION}

Soil fertility is the inherent ability of soil to supply nutrients for plant growth and development in adequate and required proportion without any detrimental or toxic effect (Esu, 2010). Igbokwe (1982) had identified soil properties such as $\mathrm{pH}$, cation exchange capacity (CEC) and percentage base saturation (BS) as important indices in the determination of the degree of soil fertility.

Cassava (Manihotesculentus) is an important staple crop globally for generating income and food security (Abuaet al., 2010). About 160 million people, or $40 \%$ of the Nigerian population,

Journal of the Faculty of Agriculture and Veterinary Medicine, Imo State University Owerri website: wwwajol.info 
consume cassava as a staple food (Nweke, 2002). Cassava plays a crucial role as energy food, available all year round year round availability, tolerant to stress and suitability for most present farming systems, (Nweke, 2002). In recent time, there have been decrease in the yield of cassava which can be traced to the poor nutrient status of soil, lack of scientific research information for effective soil management, excessive rainfall and leaching, nutrient depletion, rapid mineralization of soil organic matter and excessive cultivation of land due to increase in human population (IITA, 1995).

According to Howeler(2002), cassava has a higher tolerance for much lower critical level of available phosphorus than less mycorrhizal dependent crops like maize and beans and is able to grow relatively well on soils with a weak capacity to supply phosphorus. It is also well adapted to acidic soils due to its tolerance to low $\mathrm{pH}$ and exchangeable aluminum. It can tolerate more water stress and high water use efficiency than many other crops, (El-Sharkawy, 2004).

However, studies on fertility status of soils used for cassava production in Owerri, Imo State is relatively scarce. Thus, this study was conducted to assess the fertility status of soils predominantly used for cassava production in Owerri and to generate suitable recommendation for improved soil and cassava production capacity of the soils.

\section{MATERIALS AND METHODS Study Area}

The study was conducted in Owerri, Imo State lying between latitudes $5^{\circ} 20^{\prime} \mathrm{N}$ and $6^{\circ} 55^{\prime} \mathrm{N}$ and longitudes $6^{\circ} 35^{\prime} \mathrm{E}$ and $7^{\circ} 08^{\prime} \mathrm{E}$. The area is underlaid by coastal plain sands, and is generally lowlying and dominated by low lands. The climate is humid tropical with rainy season of about 9 months with 3 dry months, in a year. Mean annual rainfall is about 2,500 $\mathrm{mm}$, temperature is $27^{\circ} \mathrm{C}$ and relative humidity of about $85 \%$. It has typical rainforest vegetation with plants arranged in tiers with oil palms (Elaeisguineensis) as one of the dominant plant species. Agriculture is the major occupation of the people in the area.

Sampling Sites: Ten locations were chosen for the study. They include Amakohia, Akwakuma, Egbu, Orji, Uratta, Emii, Emekuku, Naze, Nekede and Oforola. At each study site an area measuring $10 \mathrm{~m}$ x 10m was mapped out. Soil samples were collected randomly from soil depths of, $0-15 \mathrm{~cm}$ and $15-30 \mathrm{~cm}$ respectively. A total of twenty (20) samples were used for the study. The soil samples were air dried and sieved with $2 \mathrm{~mm}$ sieve.

\section{Laboratory Analysis}

Particle size distribution was determined by hydrometer method (Gee and Or., 2002). Bulk density was determined by oven-drying the samples to constant weight at $105^{\circ} \mathrm{C}$ and bulk density computed as described by Klute (1996). The soil pH was determined in both distilled water and $0.1 \mathrm{~N}$ KCL solution (Mclean, 1982). The soil organic carbon was determined by digestion Journal of the Faculty of Agriculture and Veterinary Medicine, Imo State University Owerri website: wwwajol.info 
method (Nelson and Sommers, 1982). While, the soil organic matter content was obtained by multiplying organic carbon values by 1.724 . Total nitrogen was determined in accordance with Bremner and Mulvaney, (1982). The extractable phosphorus was determined by Bray II method as described by Nelson and Sommers (1982). The exchangeable cations were obtained by the method described by Thomas (1982). Potassium, and sodium ions were determined using the flame photometer method while magnesium, and calcium ions were determined using the atomic absorption spectrophotometer (AAS).

\section{Statistical Analysis}

Data collected were analyzed using simple descriptive statistics such as arithmetic means, Standard Deviation (SD) and Coefficient of Variation (CV).

\section{Results and Discussion}

Result of soil physical properties at $0-15 \mathrm{~cm}$ and $15-30 \mathrm{~cm}$ depths are shown in Table 1. Particle size distribution was dominated by the sand fractions in all the study areas. Texture of the surface soils was generally sandy loam, while that of subsurface was sandy clay loam. High proportion of sand may be attributed to property inherited from the parent material. Sand content of the soils in south-eastern region of the country is characteristic of sand formed on unconsolidated coastal plain (FDALR. 1987) Akamigbo and Asadu (1986) observed that textures of soils in southeastern Nigeria are related to their parent materials. Silt fraction ranged from $5.00-8.00 \%$ with a mean of $7.30 \%$ in surface soil and $4.00-8.00 \%$ with a mean of $6.20 \%$ in subsurface. Clay fractions at surface soil ranged from $12.40 \%-20-40 \%$ with a mean of $25.39 \%$. Highest clay fraction of $30.40 \%$ was observed in the subsoil and lowest clay contents of $12.40 \%$ in surface soil. This finding agreed with the report of Ukaegbu and Akamigbo (2005) that clay contents in the subsoil are higher than in the topsoil. Bulk density varied little across the two depths and ranged from $1.59-2.01 \mathrm{~g} / \mathrm{cm}^{3}$ with a mean of $1.80 \mathrm{~g} / \mathrm{cm}^{3}$ in the surface soil, subsurface ranged from $1.87-2.44 \mathrm{~g} / \mathrm{cm}^{3}$ with a mean of $2.04 \mathrm{~g} / \mathrm{cm}^{3}$. These results may be due to the slaking siltation and compaction of soil. Ahukaemereet al., (2012) observed consistently higher bulk density in continuously cultivated land.

The chemical properties of the soil showed little variation at both depths with co-efficient of variation of $0.03-55.55 \%$ (Table 2). The $\mathrm{pH}$ ranged from 4.86-5.56 with a mean of 5.29 at 0-15 $\mathrm{cm}$ depth while at $15-30 \mathrm{~cm}$ depths $\mathrm{pH}$ ranged from 5.17 -5.44 with a mean of 5.29. The $\mathrm{pH}$ of soils evaluated were qualified as strongly to moderately acidic. The observed $\mathrm{pH}$ in the study area might be associated with removal of bases through crop harvest and leaching of basic cations (Abuaet al., 2010). The content of organic carbon had mean value of $1.2 \%$ in the surface, and $1.05 \%$ in the subsurface soil and were rated low. Chudeet al., (2011). This can be attributed to the generally low nutrient content of the parent materials (Coastal Plain Sands) and to the strongly acidic chemical condition of the soils as well as to high rainfall and temperature 
of the area, (FDALR, 1987). Total nitrogen content of the soils ranged from $0.08 \%$ to $0.16 \%$ at the surface with mean value of $0.11 \%$ and $0.05 \%$ to $0.14 \%$ at subsurface with a mean $0.09 \%$. This observation is consistent with the findings of Ukaegbu and Akamigbo (2005) who reported average total $\mathrm{N}$ percentage of 0.08 in soils of the cross river coastal plain sands. Onyekwere et al. (2003) pointed out that low total nitrogen level of soils must be a reflection of the organic carbon content in the soil as observed in the present study. However, the total nitrogen of all sites are generally low compared to the rating of soils of southeastern Nigeria. Available phosphorus content in both surface and subsurface soils, respectively of $(10.02-23.10 \mathrm{mg} / \mathrm{kg})$ is considered high. The high level of $\mathrm{P}$ in this study was surprising and may be related to high use of phosphatic fertilizers as revealed by the rural farmers at the time of my interaction with them. The proportions of exchangeable bases ( $\mathrm{Ca}, \mathrm{Mg}, \mathrm{Na}$ and $\mathrm{K}$ ) were low across the test soils. Low levels of $\mathrm{Ca}, \mathrm{Mg}$ and $\mathrm{K}$ have been reported for most Nigerian soils (Uzohoet al., 2007) and are attributed to losses from leaching due to the high tropical rainfall as well as low content of the elements in the parent rock. However, critical values of exchangeable cations have been reported by various researchers. For instance, Adeoye and Agboola (1984) reported critical values of 2.0, 0.4 and $0.20 \mathrm{cmol} / \mathrm{kg}$ for $\mathrm{Ca}, \mathrm{Mg}$ and $\mathrm{K}$ respectively. However, on comparative, basis the high level of exchangeable $\mathrm{Ca}$, and $\mathrm{Mg}$ over $\mathrm{K}$ and $\mathrm{Na}$ agreed with the findings of Pitty (2014), who stated that $\mathrm{Ca}$ and $\mathrm{Mg}$ are predominant cations in soils as a result of their strong adsorption and rapid release into the soil system through soil mineral weathering. The $\mathrm{Ca}: \mathrm{Mg}$ ratio, $\mathrm{K}: \mathrm{Mg}$ ratio in the surface and subsurface soil is low, ranged from 1:1-2:1, $\mathrm{K}: \mathrm{Mg}$ 1:2-1:10 respectively. University of Missouri (1991) reported that the $\mathrm{Ca}: \mathrm{Ma}, \mathrm{K}: \mathrm{Mg}$ ratio of most fertile soils ranges from 5:1 to 8:1 but in low fertile soils, the ratio could be as low as 2:1.

The cation exchange capacity in the surface soil ranged from $3.50-9.36 \mathrm{cmol} / \mathrm{kg}$ with a mean value of $6.36 \mathrm{cmol} / \mathrm{kg}$, in the subsurface the range is 4.45 to $5.94 \mathrm{cmol} / \mathrm{kg}$ with a mean of $5.0 \pm$ $0.49 \mathrm{cmol} / \mathrm{kg}$ and standard deviation of 0.49 . However, the cation exchange capacity values obtained in this study were below the value of $20 \mathrm{cmol} / \mathrm{kg}$ reported as being suitable for crop production (FAO, 1995). The base saturation level of the surface soils ranged from 65.0$89.35 \mathrm{~g} / \mathrm{kg}$ with a mean value of $79.18 \mathrm{~g} / \mathrm{kg}$ and standard $79.18 \pm 7.66 \mathrm{~g} / \mathrm{kg}$ deviation of 7.66 while in the sub-surface soils base saturation ranged from $72.6-82.7 \mathrm{~g} / \mathrm{kg}$ with mean value of $77.93 \mathrm{~g} / \mathrm{kg}$ and standard deviation of $77.93 \pm 3.4 \mathrm{~g} / \mathrm{kg}$. Thus, the base saturation was high implying saturation of the soil exchange complex with bases. In the contrary, the low cation values recorded in these soils might be as a result of rapid crop uptake of the cations or possible losses through leaching due to excessive rainfall characteristics of the area.

\section{CONCLUSION AND RECOMMENDATIONS}

Soils of the study area are mainly loamy sand at the surface, sandy clay loam at subsurface and strongly to moderately acidic in all the pedons. All the fertility indices which include organic matter content, total nitrogen, effective cation exchange capacity and basic cations except base

Journal of the Faculty of Agriculture and Veterinary Medicine, Imo State University Owerri website: wwwajol.info 
saturation were found to be entirely low compared with known fertility standards. For the fertility status of the soils to be improved, for better productivity, appropriate inorganic fertilizers and manures should be properly applied, liming and mulching should also be recommended.

Journal of the Faculty of Agriculture and Veterinary Medicine, Imo State University Owerri website: wwwajol.info 


\section{REFERENCES}

Adeoye, G.O. and Agboola, A. A. (1985). Critical levels for soil pH, Available P, K, Zn and Mn and Maize Ear-leaf content of $\mathrm{P}, \mathrm{Cu}$ and $\mathrm{Mn}$ in sedimentary soils of South Western Nigeria. Fertilizer Research, 6: 65-75.

Abua, M.A., Offiong, R.A. Iwara, A.I. and Ibor, U.W. (2010). Impact of Newly Constructed Roads on Adjoining soil properties in Tinapapa Resort, South-Eastern Nigeria. Annals of Humanities and Development Studies 1(1), 176-184.

Ahukaemere, C.M, Ndukwu B.N. and Agim I.C, (2012). Soil Quality and Soil degradation as Influenced by Agricultural Land use Types in the Humid Environment. International Journal of forest, soil and Erosion, 2(4): 23-28.

Akamigbo F.O.R. and Asadu, C.L.A (1986). The influence oftoposequence on some soil properties in selected areas of Anambra State, S.E. Nigeria. J. of Soil Sci. 6:35-46.

Bremner J.M. and Mulvaney, F.S. (1982). Nitrogen-Total in D.L. Sperks (Ed.) Methods of soil Analysis, part 3. Soil Science Society of America Book series 5, Madison, USA. Pp. 1085-1122.

Chude, V.O. Iwuafor E.N.O., Amapu I.V. Pam S.G. and Yusuf A.A., (2001). Response of Cassava to Zinc Fertilization in relation to Mehlich III extractable Zinc. In Badu, Apraku B. et al., (editors), Proc. of a regional cassava workshop IITA Cotonou, Benin Republic. 14-18 2001. Wecaman\IITA; Pp. 201-207.

Chude, V.O. Malgwi, W.B. Amapu. I.V. and Ano, A.O. (2011). Manual on Soil Fertility Assessment. Federal Fertilizer Department. FAO and National Programme on food Security, Abuja, Nigeria. 62.Pp.

El- Sharkawy, M.A. (2004) Cassava Biology and Physiology. Plant Mol. Biol. Pp. 481-501.

Esu I.E. (2010). Soil Characterization: classification and survey. HEBN Publishers PLC. Ibadan, Nigeria.

FAO (Food and Agricultural Organization)(1998) Guidelines for soil profile description, Rome Pp 66-69.

FDALR (Federal Department of Agricultural Land Resources (1987). Reconnaissance soil map of Nigeria Federal Ministry of Agriculture and Rural Development, Abuja.

Gee, G.W. and Or (2002). Particle size analysis In: Method of soil analysis part 2, (Eds Page A.L., Miller R.H. and Keeney, D.R.) America Society of Agronomy, Madison, WI, Pp. 383-308.

Journal of the Faculty of Agriculture and Veterinary Medicine, Imo State University Owerri website: wwwajol.info 
Howeler R.H. (2002). Cassava, Mineral Nutrition and Fertilization. In: Hillocks R.J. Thresh M.J. Bellotti A.C. (editors). Cassava: Biology, Production and Utilization. Pp. 115-147.

Igbokwe, M.C. (1982). A review of soil fertility investigation in the Eastern states of Nigeria. Invited paper, soil fertility workshop, NRCRI, Umudike-Umuahia.

IITA (International Institute of Tropical Agriculture), (1995). Cassava in Tropical Africa. A Reference Manual, IITA, Ibadan, Pp. 175-176.

Klute, A.(1996) (Methods of Soil Analysis (PI): Physical and Mineralogical methods). America society of Agronomy, Madison; 284-312.

Mclean, E.O. (1982). Soil pH and Liming Requirement in: A.L. Pagel et al., (Eds.) Methods of Soil Analysis Part 2.2 ${ }^{\text {nd }}$ (Edn.). Agron. Mono, ASA and SSSA, Madison, Wisconsin, USA, 679-820.

Nelson, D.W. and Sommers, L.E. (1982). Total Carbon, Organic carbon and organic matter, D.L. Sparka (Editor). Methods of soil analysis, part 3, Chemical method, Soil Science Society of America series 5, Madison, Wisconsin, USA, Pp. 961-101.

Onyekwere, I.N. Ano, A. O. Osunde, A.O. and Bala, A.O. (2003). Assessment of Exchangeable acidity status and management of Wet soils of Cross River State. Nigeria Agriculture Productivity and Environment. Vol. 3(1): 202-207.

Pitty, A.E. (2014). Geographic and Soil Properties, Methanan Company, Oxford University, Publisher, Pp. 103-105.

Thomas, G.W. (1982). Exchangeable cations. Methods of soil analysis, part II. Agronomy monograph 9. ( $3^{\text {rd }}$ edition) America Soil Association and Soil Science Society of America, Madison Wisconsin.

Ukaegbu, E.P. and Akamigbo, F.O. R. (2005). Influence of Physiography on the Properties and use of soils of the Cross River Plain: A Case study of a strip of land at Isiagu, Ebonyi State, In proceedings $29^{\text {th }}$ Ann. Conf. Soil Sc. Soc. Nigeria, Pp.103-109.

University of Missouri (1999). Calcium to Magnesium, Potassium to Magnesium./ spectrum Analytic INC. 87 Jamicon Rd, NW. Missouri, USA, 20pp.

Uzoho, B. U. Oti, N.N. and Ngwuta, A. (2007). Fertility status under Land use types on soils of similar Lithology. Journal of American Science, 3(4): 20-29.

Journal of the Faculty of Agriculture and Veterinary Medicine, Imo State University Owerri website: wwwajol.info 
Volume 15 Number2, October 2017 pp. 1- 10.

Table 1: Soil Physical Properties of the Study Area

\begin{tabular}{llllll}
\hline $\begin{array}{l}\text { Sampling } \\
\text { Site }\end{array}$ & $\begin{array}{l}\text { Sand } \\
\left(\mathbf{g k g}^{-\mathbf{1}}\right)\end{array}$ & $\begin{array}{l}\text { Silt } \\
\left(\mathbf{g k g}^{-\mathbf{1}}\right)\end{array}$ & $\begin{array}{l}\text { Clay } \\
\left(\mathbf{g k g}^{-\mathbf{1}}\right)\end{array}$ & $\begin{array}{l}\text { Textural } \\
\text { Class }\end{array}$ & $\begin{array}{l}\text { Bulk } \\
\text { Dens } \\
(\mathbf{g} / \mathbf{c m}\end{array}$ \\
\hline & & $\begin{array}{l}\mathbf{( 0 - 1 5 c m}) \\
\text { depth }\end{array}$ & & & \\
Amakohia & 716.0 & 100.0 & 184.0 & SL & 1.75 \\
Akwakuma & 796.0 & 80.0 & 124.0 & SL & 1.68 \\
Egbu & 776.0 & 60.0 & 164.0 & SL & 1.82 \\
Orji & 736.0 & 60.0 & 204.0 & SL & 2.01 \\
Uratta & 716.0 & 100.0 & 184.0 & SL & 1.66 \\
Emii & 736.0 & 60.0 & 204.0 & SL & 1.95 \\
Emekuku & 776.0 & 80.0 & 144.0 & SL & 2.00 \\
Naze & 746.0 & 50.0 & 204.0 & SL & 1.77 \\
Nekede & 766.0 & 60.0 & 174.0 & SL & 1.86 \\
Oforola & 786.0 & 80.0 & 134.0 & SL & 1.59 \\
Mean & $\mathbf{7 5 . 5 0}$ & $\mathbf{7 . 3 0}$ & $\mathbf{1 7 . 2 0}$ & & $\mathbf{1 . 8 0}$ \\
STD & $\mathbf{2 . 9 0}$ & $\mathbf{1 . 7 7}$ & $\mathbf{3 . 0 0}$ & & $\mathbf{0 . 1 5}$ \\
CV(\%) & $\mathbf{3 . 8 2}$ & $\mathbf{4 . 2 1}$ & $\mathbf{1 7 . 2 9}$ & & $\mathbf{8 . 0 1}$
\end{tabular}

\section{$(15-30 \mathrm{~cm})$ depth}

\begin{tabular}{llllll} 
Amakohia & 656.0 & 80.0 & 264.0 & SCL & 1.72 \\
Akwakuma & 696.0 & 80.0 & 224.0 & SCL & 1.98 \\
Egbu & 677.0 & 40.0 & 283.0 & SCL & 1.98 \\
Orji & 636.0 & 60.0 & 304.0 & SCL & 2.34 \\
Uratta & 696.0 & 40.0 & 264.0 & SCL & 1.87 \\
Emii & 716.0 & 60.0 & 224.0 & SCL & 2.03 \\
Emekuku & 676.0 & 80.0 & 244.0 & SCL & 2.44 \\
Naze & 696.0 & 40.0 & 264.0 & SCL & 1.89 \\
Nekede & 686.0 & 60.0 & 254.0 & SCL & 2.15 \\
Oforola & 686.0 & 80.0 & 234.0 & SCL & 1.92 \\
Mean & $\mathbf{6 8 . 2 1}$ & $\mathbf{6 . 2 0}$ & $\mathbf{2 5 . 3 9}$ & & $\mathbf{2 . 0 4}$ \\
STD & $\mathbf{2 . 2 7}$ & $\mathbf{1 . 7 5}$ & $\mathbf{2 . 7 4}$ & & $\mathbf{0 . 1 9}$ \\
CV(\%) & $\mathbf{3 . 3 3}$ & $\mathbf{2 8 . 2 5}$ & $\mathbf{1 0 . 7 8}$ & & $\mathbf{9 . 3 1}$ \\
\hline
\end{tabular}

$\mathrm{SL}=$ Sandy Loam, STD $=$ Standard Deviation, $\mathrm{SCL}=$ Sandy Clay Loam, CV= Coefficient of Variation 
Table 2: Soil Chemical Properties of the Study Area

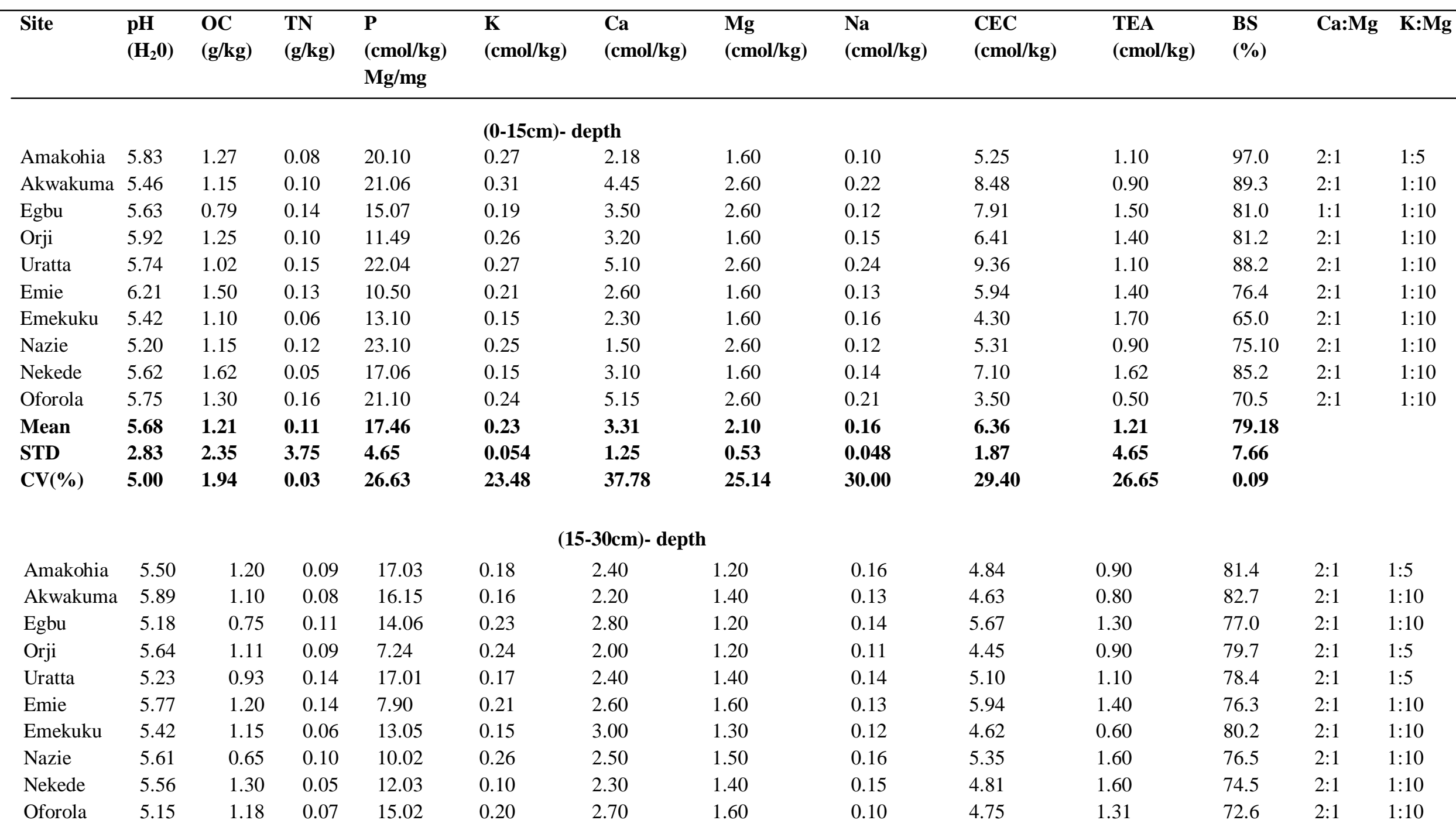

Journal of the Faculty of Agriculture and Veterinary Medicine, Imo State University Owerri website: wwwajol.info 
Journal of Agriculture and Food Sciences

Volume 15 Number2, October 2017 pp. 1- 10.

Chinyere Chikere-Njokun

10

\begin{tabular}{llllllllllll} 
Mean & 5.58 & 1.05 & 0.09 & 12.95 & 0.19 & 2.49 & 1.38 & 0.13 & 5.01 & 1.05 & 77.93 \\
STD & 1.48 & 0.21 & 0.030 & 3.59 & 0.47 & 0.29 & 0.15 & 0.02 & 0.89 & 0.34 & 3.14 \\
CV $(\%)$ & 25.52 & 20.00 & 33.33 & 27.72 & 24.74 & 11.65 & 10.87 & 15.0 & 9.78 & 32.88 & 4.02 \\
\hline
\end{tabular}

$\mathrm{OC}=$ organic carbon, $\mathrm{TN}=$ total nitrogen, AVP: available phosphorus, Exch. $\mathrm{K}=$ exchangeable potassium, Exch $\mathrm{Ca}=$ exchangeable calcium, Exch. $\mathrm{Mg}=$ exchangeable magnesium. Exch. $\mathrm{Na}=$ Exchangeable Sodium, $\mathrm{CEC}=$ cation exchange Bsat= base saturation, Ca:Mg Calcium: Magnesium Ratio, K:Mg- Potassium: Magnesium Ratio. 